\title{
APP-035 当科における膀胱全摘術の時代による治療成績
}

千葉大学医学部泌尿器科 ${ }^{1)}$, 千葉大学フロンティアメディカルエ学研究開発センター2)

戸辺 豊総1), 納谷 幸男 ${ }^{11}$, 荒木 千裕 ${ }^{1}$, 巣山 貴仁 ${ }^{11}$, 鈴木 啓悦 ${ }^{11}$, 今本 敬 ${ }^{11}$, 五十嵐 辰夫 ${ }^{21}$, 市川 智彦 ${ }^{11}$ 【目的】当科の膀胱全摘術につき年代の経過がその治療成績の向上に寄与しているか検討した。【対象と方法】1975 年 1 月から 2005 年 1 月までに当科にて施行した膀胱全摘術 276 例を対象とした。患者背景は男性 216 例，女性 60 例. 年齢は 41〜87 歳 (中央値 67 歳). 観察期間は 1 237 ヶ月 (中央值 24 ケ月)である. これらの症例につき retrospective に年代別の治療成績につき検討した．年代は 1975〜1984 年を 1 期，1985～1994 年を 2 期，1995～2004 年を 3 期とした。 また病期は pT2 以下かつリンパ節転移のないものを organ confined 群 (OC 群), それ以外を extra vesical 群 (EV 群) とした.【結果】 OC 群と EV 群は 157 例と 119 例であった。また 1 期は 72 例, 2 期は 110 例, 3 期は 94 例であった. 1 期における $\mathrm{OC} / \mathrm{EV}$ 群の割合は 40/32,2 期の $\mathrm{OC} / \mathrm{EV}$ 群は 74/36,3 期の OC/EV 群は $43 / 51$ であった。 OC 群と EV 群は 5 年生存率 $80.8 \%$ と $36.3 \%$ で, 予後に差を認めた $(\mathrm{p}<0.01)$. OC 群に㧍ける年 代別の治療成績 5 年生存率は 1 期 $73.3 \%, 2$ 期 $82.1 \%, 3$ 期 $87.2 \%$ であった. EV 群に抢ける年代別の治療成績 5 年生存率は 1 期 $27.5 \%, 2$ 期 $35.4 .1 \%, 3$ 期 43.4\% であり，50\% 生存期間は， 1 期 14 ヶ月，3期 29.6 ヶ月であった. 1 期と 3 期を比較すると治療成績改善傾向は認められた $(\mathrm{p}=0.07)$.【結語】時代の経過とともに膀胱全摘術の治療 成績は改善傾向にあると思われるが, 限界もある. 今後の全摘術の治療の方向性は OC 群に掠いては, 術後の QOL の重視を, EV 群においては新規抗癌剤等の導入による生存率の更なる向上を目指すべきであると思われた.

\section{APP-036 表在性腤胱癌再発予防における BCG40mg 膀注療法の有用性（80mgに对する前向き比較試験）}

\section{弘前大学医学部泌尿器科}

今井 篤, 岡本 亜希子, 石村 大史, 盛 和行, 畠山 真吾, 萩沢 茂, 米山 高弘, 古家 挀也, 大和 隆, 大山 力 【目的】表在性膀胱癌に対する TURBT 後の再発子防を目的とした BCG 膀胱内注入療法の有用性は広く認められて いるが, 高率に出現する副作用が問題となっている. 治療効果を損なわず，副作用を如何に軽減させるかが課題と なっている. BCGの一回投与量を減らす試みも報告されているが, そのエビデンスは充分ではない. そこで我々は, BCG 膀胱内注入療法における $40 \mathrm{mg}$ 投与の再発予防効果及び副作用を確認するため, 前向き研究を行った. 今回そ の長期成績に関し報告する.【対象と方法】 historical control は，1988 年より 2000 年まで BCG80mg を投与した 84 例（男性 60 例，女性 24 例）で, 観察期間は平均 43.3 ヶ月，年齢は平均 65.4 才であった。 G2 64 例，G3 19 例， Ta 17 例，T1 67 例であった，BCG40mg 投与群は 1995 年から 2005 年 8 月まで一回 $40 \mathrm{mg}$ を投与した 54 例（男性 44 例，女性 10 例）で, 観察期間は平均 34.9 ヶ月，年齢は平均 70.1 才であった. G2 38 例, G3 16 例, Ta 7 例, T 147 例であった. 患者背景に有意差は認めなかった. BCGの投与方法は, TURBT1-2 週後, 生理食塩水 $40 \mathrm{ml}$ に熟 濁し, 膀胱内に 2 時間保持させた。週 1 回, 計 6 週投与した. 非再発率の計算は Kaplan-Meier 法にて行い, 統計 学的处理は $\chi$ 二乗検定，一般化 Willcoxon 検定を用い，危険率 $5 \%$ 未満を有意とした.【結果】 $40 \mathrm{mg}$ 投与群の非再 発率は, 1 年 $78.6 \%, 3$ 年 $59.4 \%, 5$ 年 $59.4 \%$ であった. $80 \mathrm{mg}$ 投与群では各々 $81.5 \%, 67.4 \%, 64.6 \%$ であり, 両群 間に有意差を認めなかった．副作用出現率は，40mg 投与群 $59.3 \%, 80 \mathrm{mg}$ 投与群 $79.8 \%$ で, $40 \mathrm{mg}$ 投与群で有意に 低かった $(\mathrm{p}<0.05)$.【結論】 $\mathrm{BCG}$ 一回投与量を $40 \mathrm{mg}$ に減量しても再発予防効果に差は無く, 副作用の出現率は 有意に低かった，表在性膀胱癌に対する再発子防に関しては，40mg 投与の有用性が優っていると思われた. 